FRANCESCO PIRA

ORCID: 0000-0002-6842-2950

University of Messina

\title{
From "pizzini" to social media channel: The mediatic storytelling of mafia language
}

DOI: 10.19195/2083-7763.9.15

\section{Introduction}

We intend to provide an analysis of how the media representation of the mafia language has turned into storytelling and how this has influenced public opinion and the perception of organized crime in Italian society. The communication tools used within the clans have often become the subject of a representation that has thinned the boundary between reality and its representation, where reality, through the representation of the media, as Baudrillard argues, is shaped, or even determined by the media (Giddens, Sutton 2013, p. 285).

The communicative style of the mafia has always been characterized as the result of communication "by subtraction". From the nineteenth-century oral tradition, through the "pizzini", ${ }^{1}$ to the use of information technologies to manage financial flows and illicit trafficking, they always made use of an essential communication, a conspiratorial language. In the most critical phase of the conflict between the Italian State Institutions and criminal organizations, the strategy of the mafia included actions supposed to maintain its media representation, with the aim of instilling fear and uncertainty in citizens and to demonstrate its strength and its control over the territory.

A report on social security and insecurity in Italy and in Europe (Demos \& Pi, Osservatorio di Pavia per Fondazione Unipolis 2017) shows that 78\% of Italians

${ }^{1}$ Pizzino, noun, derived from Sicilian dialect pizzinu, meaning a small piece of paper, card. In the jargon of the mafia pizzini are the cripted messages written by the boss and adressed to the affiliates (this is to avoid interceptions). They are delivered through a sophisticated network of intermediaries, see Treccani.it/vocabolario/pizzino (accessed: 17.10.2018). 
believes that crime has grown in Italy, but they associate this phenomenon with the increase in migration flows, even if the data on the number of criminal actions are decreasing. This highlights how in the social age perception prevails over reality itself. In the agenda setting of the Italian media and in particular of television, the representations of migratory flows, the fear of terrorism, the episodes of common crime, robberies and common murders appear more relevant than the fight against the mafias.

This distorted representation of reality facilitates the exercise of the "sweet power" of organized crime, which operates in a more unseen way, increasing its influence. This evolution is immersed in the social context, where culture and knowledge are threatened by the increasing inability of individuals to interpret reality.

\section{The evolution of mafia's communication style}

As we have introduced above, the communicative style of the mafia has always been characterized as the result of communication "by subtraction". The language in the mafia's strategy is an instrument of power. It serves a very specific use. It does not want to be an instrument of relationship (Gili, Colombo 2012, p. 302), but rather an instrument of managed power. ${ }^{2}$ There is no objectification ${ }^{3}$ process in this use of language.

Even if the mafia has taken advantage of spectacularization, it has gone back to the fundamentals of its own identity profile, which can be characterized as a medium of messages typical of the "mafia culture", based on the prevailing of empathy instead of rational thinking. It is an instrument of internal communication, which in its structure seems to refer to the "oral culture" as described by Ong (1982, pp. 3142). This has given life to an organization that is extremely traditionalist, where the oral tale played the key role in impressing in the affiliates' memory the principal concepts of the mafia. This creates the anthropological essence of mafia. An example of this type of content is represented by the pizzini of Bernardo Provenzano, which were an instrument of communication and management of power. He was

2 This connotation of the instrument takes us back to the definition of bias introduced by Innis that circumscribes the specific property of a medium: influence, tendency, deformation, prejudice. It defines what the medium can or can not do. In this sense: "This bias is strengthened in a monopoly when some groups enter into control of the form of communication and identify with it their own interests, religious or political" (Miconi in Innis 1950 [2001], p. 31).

3 We refer to the definition of Ong which identifies the three main directions in which writing, the phonetic alphabet and the press develop and empower the human word as a means of social relation. Agreements such as the possibility of storing information in the form of documents. The ability to transmit messages at a distance and the ability to reproduce and disseminate messages to a larger number of recipients. In order for this to happen, however, it is necessary that the word be fixed, crystallized, separated from its natural context, and depersonalized, separated from its author (Ong 1982, p. 75). 
a member of Cosa Nostra and considered the chief of the clans from 1995 until his arrest which took place in 2006. Arrested on 11 April 2006 on a farm in Corleone (a village in the north west of Sicily, near Palermo), Provenzano had been wanted from 10 September 1963, with a record of 43 years spent in hiding.

The discovery of Provenzano helped Italian investigators to reveal many dynamics of Cosa Nostra. The interpretation of the pizzini, as well as the conversations between affiliates allowed investigators to delineate the mafia communication codes and helped to define the outlines of its "external communication". Two different processes took place:

1. An indirect communication that provided through the media narration a representation of the criminal acts of the mafia.

2. A direct communication through the criminals' statements, during the trials and those of some prominent members of the criminal organization released to the press (Pira, Altinier 2017, pp. 129-130).

A complex communicative weaving in a difficult historical moment. At the beginning of the 1990s, the mafia made a quantum leap in its aggression toward the Italian institutions and seemed to exploit the media as part of a communication strategy that aimed to destabilize the State and establish itself as an alternative power. It was in this context that journalists published the orders for the murder of judge Antonio Scoppelliti (May 1994) that the "capo mafia" Toto Riina released during a break in the trial. On that occasion he showed how well he understood the use of media, obtaining a visibility that obscured the facts of that day.

The process was eclipsed by the discussion on the "political" message of the accused (La Piana 2010, pp. 65-67). The disruptive effect obtained was that the "chief of the chiefs" was attributed a "credibility" in talking about politics, undermining the image of Italian state institutions and showing a great ability to leverage the contradictions of Italian politics. The use of the word "communists" was borrowed from the style of Silvio Berlusconi's speech, who in January of the same year, 1994, announced with a video message his "descent into the field". Thus, the classic categories of Italian political opposition were revitalized.

During those years we assisted to a fragmentation process that undermined some values of Italian society. In such a complex perspective even the mafia's criminal strategy and the connected actions played a role in the growth of the distrust sentiment of Italian citizens towards the Institutions.

\section{The role of TV in mafia's storytelling}

Italian medias and TV in particular have played a key role in mafia's storytelling strategy. The way they show the hiding places, the habits of the captured criminals, the cars destroyed during the bomb attacks are clear examples of a setting change in the process of presenting information, this led to the prevailing of spec- 
tacularization over factual investigation. This generated a distorted perception of reality, which was often strengthened by the media through its insistence on particulars - that kind of "feticism of detail" (Cava, Pira 2015, p. 32) aroused curiosity and induced fear (Bauman 2006 [2008]). Such cases of chronicling become TV news more and more often, with the morbid attention to distressing details attracting a bigger audience. In this sense, representation prevails over comprehension.

To understand phenomena such as the organized crime of the mafia-type something more than mere information is needed. Bauman ${ }^{4}$ himself points out how modernization has led to the prevailing of the democracy of the economy over the democracy of culture, transforming it into an industrialized mass market of culture, thus subtracting instruments for interpretation and reducing more and more the space for the creation of a collective culture and instead favoring "cultural" consumerism, as a consequence of the disintegration of social bonds, of contents characterized by instantaneous fruition and performativity (Lyotard 1979 [1981], p. 121). This concept refers to the prevalence of information over knowledge, where a process of building identity based on knowledge and ethics is replaced by a self-representation in order to obtain the best possible performance for one's own public. We cancel space and time, we enter the age of the here and now, of the pervasiveness of communication flows. In such a time the "mafia communication" has found habitat and instruments to feed its own diffusion and rooting in society. ${ }^{5}$

As it has been introduced in the previous paragraph, organized crime has defined an accurate communication strategy where symbols, fear and spectacularization have played a role in creating a specific perception frame of instability and weakness of the Italian society and institutions.

\section{Mafia and the networked society}

In the era of globalization, even the mafia has adapted its profile to the new relational models, exploiting and taking full advantage of technology as a resource for the management of its financial flows and the development of criminal activities. More and more invisible, difficult to be deciphered, it exerts a power of attraction, a seductive manipulation, a "seductive power".

4 "It also takes the consideration of the mark that the 'fact' inevitably imposes on our lives and on that of other people, the 'ability to measure all this, weigh it, judge it"' (Bauman 2015, pp. 98-99).

${ }^{5}$ Castells has theorized that in the building of power "there is the deployment of a global information and communication space, as open as possible to its various participants [...]; on the other [...] one will need an information strategy to support one's own interests and values within the rules of the game". (Castells 2001, p. 154) 
With the use of force, people may be forced to do what they otherwise would rather not do. With the use of money (a large amount of money), people can be induced to do what they would not do if they were not corrupt. With the use of seduction, people can be convinced to do something for the simple pleasure of doing it. The first power aims, and rests its effectiveness, on the human survival instinct (physical or social). The second on human rapacity and avarice. The third on the human appetite of pleasure. [...] "Sweet" power is distinguished by its unique ability to recycle responsibilities as resources: instead of imposing monetary outputs (often prohibitively high), it leads to holders of lucrative financial profits; in fact, it lubricates the flywheels of our consumerist economy. [...] the ideas, completed with the evaluation of their properties and relevance, come to me (or rather they are smuggled and incorporated into my world view and toolbox) already ready: pre-selected and pre-interpreted. This puts me out of the game as an author while at the same time empowers me as an actor - I know how to proceed, how to act to avoid causing disturbance, censorship and social exclusion that would probably follow. (Bauman 2015, pp. 73-74)

In the liquid world ${ }^{6}$ the aims of organized crime haven't changed. They still are: to hold power and take advantage of networks to improve its own power and control capacity.

In the age of technological convergence these objectives appear easier to be reached. The digital society has created a false idea of freedom, that is showing its limits. The access to information occurs partially through selected channels as the social networking sites (SNS) environment directs the data flux, using more and more sophisticated algorithms and intuitive apps. This apparent ease of use gives life to the false belief of being able to control this new relational and communicative environment.

This is the post-truth era where the continuous process of creation and diffusion of documents and information generates a "documediality" culture as a consequence of specific conditions:

- virality: compared to the media world, documediality is characterized by an exponential growth of interconnections between the elements that populate the network;

- persistence: through the web the documents are forever fixed in the virtual space;

- mystification: in the network it is always easier to create fictitious identities that, for some, can become reliable sources of information;

- fragmentation: in the network the sources of information become more fragmented and detailed;

6 Bauman noted the transition from the "solid" to the "liquid" phase of modernity: "that is to say, to a condition in which the social forms (the structures that define individual choices, the institutions that guarantee the continuity of habits, the models of acceptable behavior) can no longer (nor anyone expects it) to preserve their shape for a long time, because they break up and dissolve faster than necessary time to make them take one and, once taken, to take the place assigned them" (Bauman 2006, p. v). 
- opacity: on the web authority and responsibility become difficult to be accepted. Documediality creates a "contextual fog", in which it is not clear who should impose an order on the system (Ferraris 2017, pp. 76-78).

Recent surveys conducted both at the international and national level converge on similar conclusions. Individuals use digital environments as sources of information and mainly select content using more and more aggregators built on the basis of algorithms rather than official media. This facilitates the prevailing of mystification and opacity. The false perception provided by the process of disintermediation, as an alleged exercise of full individual freedom, allows for the emergence of the inability to distinguish between reality and false representation. To these elements we have to add the progressive loss of credibility of institutions and official sources of information and knowledge (journalism, school, scientific information, church) (Pira, Altinier 2018). In line with these observations, the Digital News Report 2017 by the Reuters Institute and Oxford University highlights the strong connection existing between the distrust towards the media and the citizens' perception of political bias. This is especially evident in those countries with a strong political polarization dynamics, such as: the United States, Italy and Hungary (Reuters Institute for Study of Journalism, University of Oxford 2017, p. 9). Digital misinformation has become so pervasive in online social media that it has been listed by the World Economic Forum as one of the main threats to human society. Whether a news item, either substantiated or not, is accepted as true by a user may be strongly affected by social norms or by how much it coheres with the user's system of beliefs. Many mechanisms cause false information to gain acceptance, which in turn generates false beliefs that, once adopted by an individual, are highly resistant to correction (Del Vicario et al. 2016, p. 558)

Today, disintermediation is one of the dominant processes and has become the ideal habitat for the proliferation of fake news, because there is no more control over news flows which are shared more and more quickly, giving rise to virality and content personalization. In this sense, the phenomenon of fake news has assumed a global dimension that shows all its pervasive capacity through six characterizing elements: appeal, virality, speed, cross-mediality, flow and strength (Pira, Altinier 2018).

It is in this context that the power of organized crime exists - it has the instruments and the capacity to direct the networks. Thus increases the risk that we accept content that leads us to be subjected to the "sweet power" of seduction of temporary pleasure, culture of consumerism, personalization of our desires.

\section{Conclusions}

The evolution of mafia's language characteristics and its representation are an integral part of setting strategy that the organized crime has been able to carry out along the years: from an organization with strong roots in the territory, to a crime 
industry with influence at the global level. The mafia has been able to identify the right places in Italian society to penetrate, exploiting the growing weakness of institutions and the mistrust of Italian citizens towards them. ${ }^{7}$

This mistrust is counterbalanced by a society that shows individual behaviors less and less in line with rules and civic ethics.

The period of national consciousness arising from the mafia's massacres has exhausted, the perception of the danger that organized crime represents is weak. As we have highlighted, in the social era the perception prevails over reality. Journalistic profession is in a deep identity crisis. Politics neither confronts journalists, nor accepts the debate. The media are accused every day of not being impartial, contributing to the proliferation of fake news.

For the $87.24 \%$ of Italians there are no more opportunities to access credible news [...]. The status of the information system is therefore not related to the quality of democracy and consequently to the concept of freedom that, on the contrary, it is positively perceived by the supposed freedom granted by the network. As proof of this, for $77.30 \%$ fake news does not weaken democracy. For $75.79 \%$ the traditional information system is not exceeded. For $87.76 \%$ the information circulating on SNS are professional. (Università Suor Orsola Benicasa 2018, p. 26) ${ }^{8}$.

This contradictory perception of social environments, the inability to recognize fake news represent the most direct consequence of the phenomenon of disintermediation and that the most recent studies are pointing out that "the manipulation of public opinion on social media platforms has emerged as a critical threat to public life. All over the world, a number of government agencies and political parties are taking advantage of social media platforms to spread junk and disinformation news, censure and control and undermine trust in the media, public institutions and science. At a time when the consumption of news is increasingly digital, artificial intelligence, big data analysis and 'black-box' algorithms are exploited to undermine truth and trust: the cornerstones of our democratic society" (Bradshaw, Howard 2018, p. 3).

The spreading of "alternative truths", of manipulated visions of reality, of misinformation facilitates organized crime, which operates in a more subterranean way, increasing its influence. Faithful to itself, it maintains a cohesive structure capable of acting at a local level with the traditional tools for territorial control and at a global level able to intercept all the possibilities to feed its own power.

\section{References}

Bauman Z. (2006), Liquid Fear, Cambridge [Italian transl. Paura Liquida, Bari 2009]. Bauman Z., Mauro E. (2015), Babel, Bari.

7 Parliament and the political parties are becoming increasingly distrustful, as highlighted in the 2016 report, Gli Italiani e lo Stato (Demos \& Pi 2016).

8 Transl. by F.P. 
Bradshaw S., Howard P.N. (2018), Challenging Truth and Trust: A Global Inventory of Organized Social Media Manipulation, Oxford.

Castells M. (1996), The Rise of the Network Society, Oxford: Blackwell [Italian transl. La nascita della società in rete, Milano 2002].

Castells M. (2009), Communication Power, Oxford [Italian transl. Comunicazione e Potere, Milano 2009].

Cava A., Pira F. (2015), Social Gossip: Dalle chiacchiere di cortile al web pettegolezzo, Roma.

Commissione Parlamentare Antimafia (1993), Mafia e politica. Relazione del 6 aprile 1993, Bari.

Del Vicario M. et. al. (2016), “The spreading of misinformation online”, PNAS 113, no. 3.

Demos \& Pi, Osservatorio di Pavia per Fondazione Unipolis (2017), L'Europa sospesa tra inquietudine e speranza. Il decennio dell'incertezza globale. X Rapporto sulla sicurezza e l'insicurezza sociale in Italia e in Europa. Significati, immagini e realtà - Percezione, rappresentazione sociale e mediatica della sicurezza, http://www.demos.it/2017/pdf/4225rapporto_sulla_sicurezza_e_ insicurezza_sociale_2017.pdf (accessed: 31.01.19).

Demos \& Pi, Gli Italiani e lo Stato, Rapporto 2016, http://www.demos.it/2017/pdf/4177itasta2016_20170107.pdf (accessed: 31.01.19).

Giddens A., Sutton P.W. (2013), Sociology, 7th ed., Cambridge [Italian transl. Fondamenti di sociologia, Bologna 2014].

Jenkins H. (2009), Confronting the Challenges of Participation Culture: Media Education for the 21st Century, Boston [Italian transl. Culture partecipative e competenze digitali. Media education per il XXI secolo, Milano 2010].

Gili G. (2005), La credibilità. Quando e perché la comunicazione ha successo, Soveria Mannelli.

Gili G., Colombo F. (2012), Comunicazione, cultura, società, Milano.

Innis H.A. (1950), Empire and Communications, Oxford [Italian transl. Impero e Comunicazioni, Roma 2001].

Innis H.A. (1951), The Bias of Communication, Toronto.

La Piana G. (2010), Strategie di comunicazione mafiosa, Perugia-Ravenna.

Lyotard J.L. (1979), La condition postmoderne, Paris [Italian trans. La condizione postmoderna, Milano 1981].

McLuhan M. (1962), The Gutenberg Galaxy: The Making of Typographic Man, Toronto [Italian transl. La Galassia Gutenberg. La nascita dell'uomo tipografico, Roma 1976].

Ong J.W. (1982), Orality and Literacy: The Technologizing of the World, London.

Padovani M., Falcone G. (1991), Cose di Cosa Nostra, Milano.

Pira F., Altinier A. (2017) "Dai pizzini ai nuovi canali social. La narrazione mediatica del linguaggio mafioso", [in:] Decodifiche criminali. Saggi su illegalità e comunicazione, ed. A. Cava, S. Nucera, Roma-Messina.

Pira F., Altinier A. (2018), Giornalismi. La difficile convivenza con fake news e misnformation, Limena.

Reuters Institute for Study of Journalism, University of Oxford (2017), Digital News Report 2017, https://reutersinstitute.politics.ox.ac.uk/sites/default/files/Digital\%20News\%20Report\%20 2017\%20web_0.pdf (accessed: 31.01.19).Ferraris M. (2017), Postverità e altri enigmi, Bologna.

Università Suor Orsola Benicasa (2018), Infosfera, Report dei risultati di ricerca 2018, https://www. unisob.na.it/eventi/pdf/20180720.pdf (accessed: 31.01.19). 


\section{From "pizzini" to social media channel: The mediatic storytelling of mafia language}

\section{Summary}

We intend to provide an analysis of how the media representation of the mafia language has turned into storytelling and how this has influenced public opinion and the perception of organized crime in Italian society. The communicative style of the mafia has always been characterized as the result of communication "by subtraction". From the nineteenth-century oral tradition, through the "pizzini", to the use of information technologies to manage financial flows and illicit trafficking, they always made us of an essential communication, a conspiratorial language. In the most critical phase of the conflict between the Italian state institutions and criminal organizations, the strategy of the mafia included actions supposed to maintain its media representation, with the aim of instilling fear and uncertainty in citizens and to demonstrate its strength and its control over the territory. This distorted representation of reality facilitates the exercise of the "sweet power" of organized crime, which operates in a more unseen way, increasing its influence. This evolution is immersed in the social context, where culture and knowledge are threatened by the increasing inability of individuals to interpret reality. 